\title{
The influence of epicardial and endocardial use of cryoenergy on the completeness of lesions in surgical ablation of atrial fibrillation
}

\author{
Vojtech Kurfirst, Julia Csanady, Ales Mokracek, Jiri Hanis, Alan Bulava, Ladislav Pesl \\ Department of Cardiac and Thoracic Surgery, Hospital of České Budějovice, České Budějovice, Czech Republic
}

Kardiochir Torakochir Pol 2020; 17 (1): 29-32

\begin{abstract}
Introduction: Cryoenergy is the most commonly used method of lesion formation in patients who have undergone surgical ablation of atrial fibrillation. Despite frequent use, the clinical effect of cryoenergy in endocardial and epicardial approaches is unknown.

Aim: To compare the effect of various cryoenergy applications on the postoperative incidence of sinus rhythm and completeness of lesions performed.

Material and methods: A total of 55 patients underwent concomitant atrial fibrillation surgical ablation using cryoenergy under various conditions: epicardially during cardiac arrest, epicardially on beating heart, and endocardially. In the postoperative period, patients were invited to attend an electrophysiological examination to assess the completeness of surgical ablation lesions and, if necessary, to complete catheter ablation.

Results: Twenty-four patients underwent epicardial ablation on the arrested heart (group 1), 12 patients underwent epicardial ablation on the beating heart (group 2), and 19 patients underwent endocardial ablation (group 3). In the electrophysiological examination, sinus rhythm was present in $71 \%$ vs. $83 \%$ vs. $89 \%$ of patients, respectively. The completeness of pulmonary vein isolation was confirmed in $31 \%$ vs. $25 \%$ vs. $95 \%$ of patients, complete box lesions in $15 \%$ vs. $0 \%$ vs. $79 \%$ of patients, respectively.

Conclusions: Despite the similar clinical effect of surgical ablation in all three approaches, the morphologically most effective use of cryoenergy is endocardial ablation. This approach has a very good result. Our findings further support the endocardial use of cryoenergy during surgical ablation of atrial fibrillation.
\end{abstract}

Key words: atrial fibrillation, cryoenergy, surgical ablation.

\section{Streszczenie}

Wprowadzenie: Krioenergia jest najczęściej stosowaną metodą wytwarzania blizn u pacjentów poddawanych ablacji chirurgicznej z powodu migotania przedsionków. Pomimo popularności tej metody efekt kliniczny stosowania krioenergii z dostępu wsierdziowego i nasierdziowego nie jest znany.

Cel: Porównanie wpływu różnych zastosowań krioenergii na pooperacyjne występowanie rytmu zatokowego i kompletność zabiegu.

Materiał i metody: U łącznie 55 pacjentów wykonano jednoczesną ablację chirurgiczną migotania przedsionków z wykorzystaniem krioenergii: od strony nasierdzia po zatrzymaniu krążenia, od strony nasierdzia na bijącym sercu i od strony wsierdzia. W okresie pooperacyjnym pacjentów poproszono o zgłoszenie się na badanie elektrofizjologiczne serca, aby ocenić kompletność chirurgicznej ablacji zmian oraz w razie potrzeby uzupełnić ablację cewnikową.

Wyniki: U 24 pacjentów przeprowadzono ablację od strony nasierdzia po zatrzymaniu krążenia (grupa 1.), u 12 pacjentów - ablację od strony nasierdzia na bijącym sercu (grupa 2.), a u 19 pacjentów - ablację z dostępu wsierdziowego (grupa 3.). W badaniu elektrofizjologicznym rytm zatokowy stwierdzono u odpowiednio 71\%, 83\% i $89 \%$ pacjentów. Kompletną izolację żyły płucnej potwierdzono u odpowiednio 31\%, 25\% i 95\% pacjentów, a uszkodzenia typu „pudełka” (box lesion) u odpowiednio $15 \%$, 0\% i $79 \%$ pacjentów.

Wnioski: Pomimo zbliżonego efektu klinicznego ablacji chirurgicznej we wszystkich trzech metodach, z morfologicznego punktu widzenia najbardziej skuteczne jest stosowanie krioenergii w ablacji wsierdziowej. Technika ta daje bardzo dobry efekt. Uzyskane wyniki potwierdzają zasadność stosowania krioenergii od strony wsierdzia podczas ablacji chirurgicznej migotania przedsionków.

Słowa kluczowe: migotanie przedsionków, krioenergia, ablacja chirurgiczna.

Address for correspondence: Vojtech Kurfirst MD, PhD, Department of Cardiac and Thoracic Surgery, Hospital of České Budějovice, Boženy Němcové 54, 37001 České Budějovice, Czech Republic, phone: +42 0777237299, e-mail: vojtech.kurfirst@post.cz Received: 5.01.2020, accepted: 20.03.2020. 


\section{Introduction}

The Cox MAZE IV is the gold standard for surgical treatment of atrial fibrillation (AF) [1, 2]. However, since its introduction, many variations in the number and location of individual lesions and in the form of supplied energy have been described [3]. Cryoenergy, along with radio-frequency energy, is the most commonly used method of lesion formation in patients after surgical ablation of atrial fibrillation, with good and stable long-term results [4-6]. Despite frequent use, the clinical effect of cryoenergy in the endocardial and epicardial approaches is not sufficiently known. For these reasons, surgeons sometimes refuse to simultaneously add surgical ablation of AF to the main surgery. In clinical practice, many patients attending cardiac surgery with AF are not treated at all (up to 50\%) [7].

\section{Aim}

The aim of this study was to compare the clinical effect of various cryoenergy applications on the postoperative incidence of sinus rhythm and the completeness of lesions performed.

\section{Material and methods}

This was a single-centre, prospective study. A total of 55 patients underwent surgical ablation of AF as part of another cardiac surgery procedure (myocardial revascularisation, valve surgery, combined procedure). Before the start of the study the authors obtained approval from the institutional Ethical Committee regarding the study design. The selection criteria were: AF refractory to at least one class I or class III antiarrhythmic therapy, concomitant cardiac surgery, absence of prior catheter ablation, and written, informed consent to study participation and postoperative electrophysiological examination. The standard surgical ablation protocol includes the isolation of the pulmonary veins and the formation of a box lesion by cryoenergy under various conditions - epicardially on extracorporeal circulation and cardiac arrest, epicardial on extracorporeal circulation on the beating heart, and endocardial. A Cardioblate ${ }^{\circledR}$ CryoFlex ${ }^{\circledR}$ surgical ablation probe, Medtronic, Minneapolis, USA was used to create the lesion. The standard duration of cryoenergy application was 2 minutes at $-160^{\circ} \mathrm{C}$. The electrical insulation of the lesions was not electrically verified during the operation. All of the patients underwent left atrial appendage occlusion using an Atriclip device. In the postoperative period, treatment of AF was as follows: all patients were on anticoagulant therapy with warfarin for 3 months. If they had AF during the postoperative period, they were pharmacologically treated with Cordarone or electroconversion, and patients were given oral Cordarone for 1 month after surgery. During the postoperative period, patients were invited to attend an electrophysiological examination to assess the completeness of surgical ablation lesions and, if necessary, to supplement the lesions with catheter ablation. All catheterisation procedures were performed using the CARTO3 mapping system. None of the patients was on anti-arrhythmic therapy during electrophysiological examination. If a normal sinus rhythm was present at the beginning of the procedure, RF ablation of the cavotricuspid isthmus was performed prior to initiation of left atrial ablation. The achievement of a bidirectional block of conduction through the isthmus was determined by standard criteria. Then, after double trans-septal punctures, two controllable trans-septal sheaths (8F, Channel, BARD Electrophysiology, Lowell, MA, USA) were introduced into the left atrium (LA), and a virtual anatomy reconstruction was performed, and a bipolar voltage map obtained at least 300 points for detailed mapping of the whole LA. A circular mapping catheter (LASSO ${ }^{\circledR}$, Biosense Webster, Inc., Diamond Bar, CA, USA) was used in all veins to confirm isolation or electrical reconnection. RF energy was applied using a ThermoCool ${ }^{\circledR}$ Smart Touch $^{\mathrm{TM}}$ catheter with a $3.5 \mathrm{~mm}$ irrigated tip (Biosense Webster, Inc.) and a software module that allows contact force sensing with a temperature limitation of $44^{\circ} \mathrm{C}$ and radio-frequency energy of up to $35 \mathrm{~W}$. After reaching the insulation of all the veins (if they were reconnected), the posterior wall of the LA was mapped to confirm electrical insulation. For this purpose, the Lasso catheter was positioned so as to be perpendicular to the posterior wall. If no potentials were noted, the box lesion was considered present. If any potential was noted, both superior and inferior connecting lines were mapped to look for a gap. All gaps were subsequently ablated. Data were collected from the hospital medical electronic system and during postoperative controls by patients' surgeons.

\section{Statistical analysis}

Data are presented as mean \pm SD for continuous variables and percentages or numbers for categoric variables. Baseline clinical characteristics of patients were calculated.

\section{Results}

Twenty-four patients underwent epicardial ablation on the arrested heart (group 1), 12 patients underwent epicardial ablation on the beating heart (group 2), and 19 patients underwent endocardial ablation (group 3), as shown in Table I. The interval between cardiac surgery and electrophysiological examination was $144 \pm 138$ days (group 1) vs. 178 \pm 84 days (group 2) vs. $102 \pm 76$ days (group 3). During electrophysiological examination (Table II), sinus rhythm was present in $71 \%$ of patients $83 \%$ vs. $89 \%$ of patients in the groups 1, 2 and 3 (Figure 1). The completeness of pulmonary vein isolation was confirmed in $31 \%$ vs. $25 \%$ vs. $95 \%$ of patients and complete box lesion in $15 \%$ vs. $0 \%$ vs. $79 \%$ of patients, in the groups 1, 2 and 3 respectively (Figure 2).

\section{Discussion}

In the past, several articles were published dealing with the use of cryoenergy from the epicardial and endocardial approaches [6-16]. However, these studies were performed under laboratory conditions in an animal model, and the results were evaluated histologically in the acute phase of 
Table I. Perioperative variables

\begin{tabular}{lccc} 
Parameter & $\begin{array}{c}\text { Epicar- } \\
\text { dially }- \text { Cx. }\end{array}$ & $\begin{array}{c}\text { Epicar- } \\
\text { dially }- \text { no Cx. }\end{array}$ & $\begin{array}{c}\text { Endocar- } \\
\text { dially }\end{array}$ \\
$N$ & 24 & 12 & 19 \\
\hline Mean age [years] & $72 \pm 8$ & $73 \pm 5$ & $70 \pm 4$ \\
\hline Mean LA diameter [mm] & $48 \pm 5$ & $49 \pm 4$ & $48 \pm 4$ \\
\hline LVEF (\%) & $63 \pm 7$ & $64 \pm 7$ & $61 \pm 7$ \\
\hline Persistent AFib (\%) & 50 & 75 & 68 \\
\hline CABG (\%) & 37 & 42 & 16 \\
\hline Valve (\%) & 51 & 42 & 73 \\
\hline Combined procedure (\%) & 12 & 16 & 11 \\
\hline ECC [min] & 95 & 92 & 114 \\
\hline Cx. [min] & 50 & 35 & 81 \\
\hline Period SA-EP [days] & 144 & 178 & 102
\end{tabular}

LA - left atrium, LVEF - left ventricle ejection fraction, AFib - atrial fibrillation, CABG - coronary artery bypass grafting, ECC - extracorporeal circulation, Cx. - cross-clamp.

healing. Our work brings results from clinical practice, in which the structure of the left atrial wall is influenced by ongoing AF and the results of surgical ablation are evaluated electrophysiologically and along the entire length of the ablation line. There is also some time to create the scar after surgical ablation. This is one of the most accurate ways to evaluate the success of surgical ablation. According to available US registries, cryoenergy is used in approximately $30-50 \%$ of patients undergoing concomitant surgical ablation primarily from the epicardial approach [17].

Use of cryoenergy from the endocardial approach is an established method that encounters several obstacles: in patients without mitral and tricuspid valve defects, bicaval cannulation and opening on the left and right atria is necessary. This results in prolonged cardiac arrest interval, and a risk of air embolisation and postoperative bleeding. For these reasons, surgeons sometimes refuse to simultaneously add surgical ablation of AF to the main control. In clinical practice, many patients attending cardiac surgery with AF are not treated at all - up to 50\% [17].

Our work also shows that the clinical effect of surgical ablation in terms of maintaining sinus rhythm in the postoperative period may not be identified with the completeness of surgical lesions. The incompleteness of surgical lesions may lead to a lower incidence of sinus rhythm in the postoperative period, and individual gaps in surgical lesions may have more proarrhythmogenic potential [18-20].

The limitations of this study are particularly evident in a small number of patients. However, our results may indicate a direction for further research into the surgical use of cryoenergy.

\section{Conclusions}

Despite the similar clinical effect of surgical ablation in all three approaches, the most electrophysiologically effective use of cryoenergy is endocardial ablation. This ap-

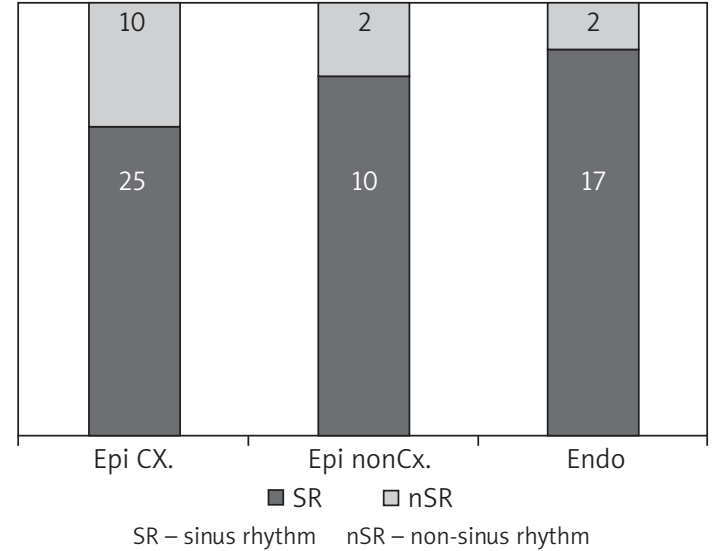

Figure 1 . The incidence of sinus rhythm

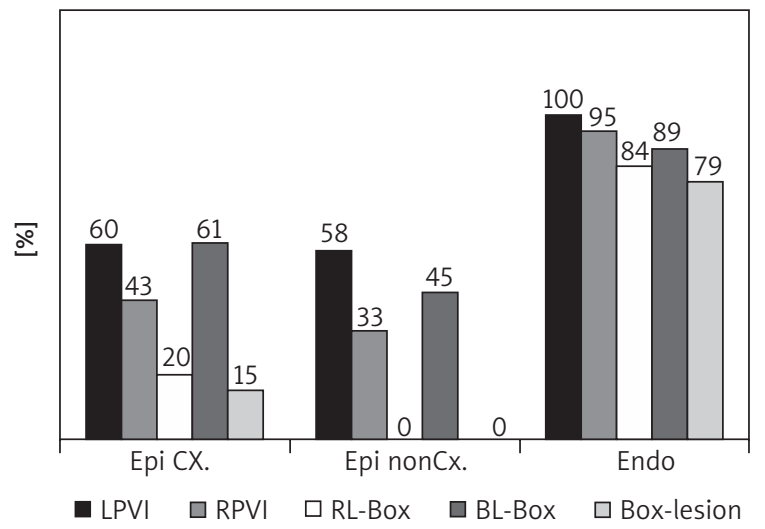

$L P V I$ - left pulmonary veins isolated, RPVI - right pulmonary veins isolated, RL-Box - roof line of box lesion, BL-Box - bottom line of box lesion

Figure 2. The completeness of lesions

Table II. Findings during the electrophysiology examination

\begin{tabular}{lccc} 
Parameter & $\begin{array}{c}\text { Epicar- } \\
\text { dially }-\mathrm{Cx} .\end{array}$ & $\begin{array}{c}\text { Epicar- } \\
\text { dially - no Cx. }\end{array}$ & $\begin{array}{c}\text { Endocar- } \\
\text { dially }\end{array}$ \\
LA volume [ml] & $141 \pm 30$ & $135 \pm 36$ & $144 \pm 22$ \\
\hline Ablation of LAT & $11 \%$ & $8 \%$ & $11 \%$ \\
\hline Ablation of RAT & $0 \%$ & $0 \%$ & $0 \%$ \\
\hline Ablation of Aflut. & $17 \%$ & $17 \%$ & $0 \%$ \\
\hline AT during testing & $31 \%$ & $33 \%$ & $14 \%$ \\
\hline Procedure time [min] & 125 & 120 & 110 \\
\hline RF time [s] & 1535 & 1543 & 771 \\
\hline RF applications $(n)$ & 25 & 26 & 13 \\
\hline
\end{tabular}

LA - left atrium, LAT - left atrial tachycardia, RAT - right atrial tachycardia, Aflut. - atrial flutter, AT - atrial tachycardia, RF - time of radiofrequency ablation, RF - radiofrequency.

proach has a very good result. Our finding further supports the endocardial use of cryoenergy during surgical ablation of atrial fibrillation, and the results of this local study have led to changes in our workplace practices.

\section{Disclosure}

The authors report no conflict of interest. 


\section{References}

1. Weimar T, Bailey MS, Watanabe Y, Marin D, Maniar HS, Schuessler RB, Damiano RJ Jr. The Cox-maze IV procedure for lone atrial fibrillation: a single center experience in 100 consecutive patients. J Interv Card Electrophysiol 2011; 31: 47-54.

2. Damiano Jr RJ, Schwartz FH, Bailey MS, Maniar HS, Munfakh NA, Moon MR, Schuessler RB. The Cox maze IV procedure: predictors of late recurrence. J Thorac Cardiovasc Surgery 2011; 141: 113-121.

3. Kirchhof P, Benussi S, Kotecha D, Ahlsson A, Atar D, Casadei B, Castella M, Diener HC, Heidbuchel H, Hendriks J, Hindricks G, Manolis AS, Oldgren J, Popescu BA, Schotten U, Van Putte B, Vardas P. 2016 ESC Guidelines for the management of atrial fibrillation developed in collaboration with EACTS: The Task Force for the management of atrial fibrillation of the European Society of Cardiology (ESC). Developed with the special contribution of the European Heart Rhythm Association (EHRA) of the ESC. Endorsed by the European Stroke Organisation (ESO). Eur Heart J 2016; 37: 2893-2962.

4. Kim JB, Cho WC, Jung SH, Chung CH, Choo SJ, Lee JW. Alternative energy sources for surgical treatment of atrial fibrillation in patients undergoing mitral valve surgery: microwave ablation vs cryoablation. J Korean Med Sci 2010; 25: 1467-1472.

5. Gaynor SL, Diodato MD, Prasad SM, Ishii Y, Schuessler RB, Bailey MS, Damiano NR, Bloch JB, Moon MR, Damiano RJ Jr. A prospective, single-center clinical trial of a modified Cox maze procedure with bipolar radiofrequency ablation. J Thorac Cardiovasc Surg 2004; 128: 535-542.

6. Hong KN, Russo MJ, Liberman EA, Trzebucki A, Oz MC, Argenziano M, Williams MR. Effect of epicardial fat on ablation performance: a three-energy source comparison. J Card Surg 2007; 22: 521-524.

7. Suwalski P, Kowalewski M, Jasinski M, Staromłyński J, Zembala M, Widenka K, Brykczyński M, Skiba J, Zembala MO, Bartuś K, Hirnle T, Dziembowska I, Deja M, Tobota Z, Maruszewski BJ. Surgical ablation for atrial fibrillation during isolated coronary artery bypass surgery. Eur J Cardiothorac Surg 2020; 57: 691-700.

8. Doll N, Kornherr P, Aupperle H, Fabricius AM, Kiaii B, Ullmann C, Schneider K, Dhein S, Schoon HA, Rastan A, Walther T, Mohr FW. Epicardial treatment of atrial fibrillation using cryoablation in an acute off-pump sheep model. Thorac Cardiovasc Surg 2003; 51: 267-273.

9. Manasse E, Colombo P, Roncalli M, Gallotti R. Myocardial acute and chronic histological modifications induced by cryoablation. Eur J Cardiothorac Surg 2000; 17: 339-340.
10. Hunt GB, Chard RB, Johnson DC, Ross DL. Comparison of early and late dimensions and arrhythmogenicity of cryolesions in the normothermic canine heart. J Thorac Cardiovasc Surg 1989; 97: 313-318.

11. Guiraudon GM, Jones DL, Skanes AC, Bainbridge D, Guiraudon CM, Jensen SM, Yuan X, Drangova M, Peters TM. En bloc exclusion of the pulmonary vein region in the pig using off pump, beating, intra-cardiac surgery: a pilot study of minimally invasive surgery for atrial fibrillation. Ann Thorac Surg 2005; 80: 1417-1423.

12. Milla F, Skubas N, Briggs WM, Girardi LN, Lee LY, Ko W, Tortolani AJ, Krieger KH, Isom W, Mack CA. Epicardial beating heart cryoablation using a novel argonbased cryoclamp and linear probe. J Thorac Cardiovasc Surg 2006; 131: 403-411.

13. Mack CA, Milla F, Ko W, Girardi LN, Lee LY, Tortolani AJ, Mascitelli J, Krieger $\mathrm{KH}$, Isom OW. Surgical treatment of atrial fibrillation using argon-based cryoablation during concomitant cardiac procedures. Circulation 2005; 112 (9 Suppl): |1-16.

14. Doll N, Kiaii BB, Fabricius AM, Bucerius J, Kornherr P, Krakor R, Gummert JF, Walther T, Mohr FW. Intraoperative left atrial ablation (for atrial fibrillation) using a new argon cryocatheter: early clinical experience. Ann Thorac Surg 2003; 76: 1711-1715.

15. Ad N, Henry L, Hunt S. The concomitant cryosurgical Cox-Maze procedure using Argon based cryoprobes: 12 month results. J Cardiovasc Surg (Torino) 2011; 52: 593-599.

16. Viola N, Williams MR, Oz MC, Ad N. The technology in use for the surgical ablation of atrial fibrillation. Semin Thorac Cardiovasc Surg 2002; 14: 198-205.

17. Badhwar V, Rankin JS, Ad N, Grau-Sepulveda M, Damiano RJ, Gillinov AM, MCCarthy PM, Thourani VH, Suri RM, Jacobs JP, Cox JL. Surgical ablation of atrial fibrillation in the United States: trends and propensity matched outcomes. Ann Thorac Surg 2017; 104: 493-500.

18. Schaff HV, Dearani JA, Daly RC, Orszulak TA, Danielson GK. Cox-Maze procedure for atrial fibrillation: Mayo Clinic experience. Semin Thorac Cardiovasc Surg 2000; 12: 30-37.

19. Mitchell MA, McRury ID, Everett TH, Li H, Mangrum JM, Haines DE. Morphological and physiological characteristics of discontinuous linear atrial ablations during atrial pacing and atrial fibrillation. J Cardiovasc Electrophysiol 1999; 10: 378-386.

20. Melby SJ, Lee AM, Zierer A, Kaiser SP, Livhits MJ, Boineau JP, Schuessler RB, Damiano RJ Jr. Atrial fibrillation propagates through gaps in ablation lines: implications for ablative treatment of atrial fibrillation. Heart Rhythm 2008; 5: 1296-1301. 